\title{
都市内農地保全に関する基礎的研究（その3)
}

\author{
让会員日 $\mathrm{日}$ 正 基*
}

1.はじめに

本稿の目的は農家の意識面での都市化・市街化圧力と の対応過程, 即ち過去において個々の農家が都市化・市 街化圧力をいかにうけとめ，それをどう行動に移してい ったのか。過去のそういった思考・行動の結果, 都市 化・市街化に対する農家意識がどう変化し，それがいか に将来の行動に反映されようとしているかを，農業観・ 農地観を通して把握する事にある。

資料としては，先に報告したアンケート調查を用い， 一部農地転用申請により補充した。アンケート内容は森 河内, 小曾根地区ともほぼ共通したものであり，有効回 答の中から $\mathrm{E}$ 型を除き $\mathrm{R}$ 型， $\mathrm{U}$ 型について集計・分 析した。その際 $R_{n}, R_{u}$ 型をあわせて農業継続型 $R$ と L, $U_{R}, U_{U}$ 型を同じく脱農型 $U$ とした。分析対象数 は森河内 40 ，小曾根 58 である。

\section{2. 森河内地区}

\section{1 過去における農家行動・行動動機}

この節においては農家行動を農地売却, 農地購入, 転 用自営行動とにわけ，各行動ごとの行動パターン・行動 動機を分折する。

(1) 農地売却・農地購入 (表-1, 2, 3, 4 参照)

昭和 30 年以降に農地を売却した農家は農業継続型で 89\%, 脱農型で $100 \%$ と殆んどの農家が農地を売却して いる。しかし農業継続型の場合, 公共事業に関連して売 却したケースが $54 \%$ と最も多く, 強制的・外的力によ
る農地売却パターンがみられる。この場合強制的・無差 別的に農地買収される結果, 生産基盤が破壊される事と なり農家は代替地を購入し, 経営の建て直しを図ると同 時に一部では転用自営に向から事によって生活の安定を 図万らとする。他方公共事業関連以外で農地を売却する 場合, 周辺市街化による生産条件悪化等の外的要因は考 えられるが，実態は農家の内的要因, 即ち臨時的多額出 費に迫られ生産条件を考慮し低生産性の，㐌るいは生産 条件の悪化した農地を売却していく。従ってその場合, 農業生産への影響は小さく, 代替地購入の必要性はない

表一3 農地購入理由（単位：回答数，2 愐目以内の選択）

\begin{tabular}{|c|c|c|c|c|c|c|c|c|c|}
\hline & $\begin{array}{l}\text { 代 } \\
\text { 替 } \\
\text { 地 }\end{array}$ & $\begin{array}{c}\text { 経規拡 } \\
\text { 模 } \\
\text { 営の大 }\end{array}$ & 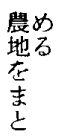 & $\begin{array}{l}\text { 優 } \\
\text { 良 } \\
\text { 農 } \\
\text { 地 }\end{array}$ & 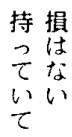 & $\begin{array}{l}\text { 持之独 } \\
\text { つ食は } \\
\text { てい } \\
\text { つは } \\
\text { るぐ }\end{array}$ & $\begin{array}{l}\text { } \\
\text { 他 }\end{array}$ & $\begin{array}{l}\text { 購 } \\
\text { 磨 } \\
\text { 蒙 } \\
\text { 数 }\end{array}$ \\
\hline \multirow{2}{*}{$\begin{array}{l}\text { 森 } \\
\text { 河 }\end{array}$} & $R$ & 15 & 2 & 1 & 3 & 2 & 4 & 0 & $19 \bar{P}$ \\
\hline & $\mathrm{U}$ & 6 & 0 & 0 & 0 & 3 & 2 & 0 & $10 \bar{\Gamma}$ \\
\hline \multirow{2}{*}{$\begin{array}{l}\text { 小 } \\
\text { 賁 }\end{array}$} & $\mathrm{R}$ & 7 & 1 & 0 & 0 & 1 & 2 & 1 & 13 戸 \\
\hline & $\mathrm{U}$ & 11 & 1 & 1 & 0 & 5 & 3 & 1 & $20 \bar{戸}$ \\
\hline
\end{tabular}

表一4 公共事業と農家行動（森河内）

\begin{tabular}{|c|c|c|c|c|}
\hline & \multicolumn{3}{|c|}{ 代替地瞒入農家率 } & \multirow{2}{*}{$\begin{array}{l}\text { 公挂事業以降に転用 } \\
\text { 自営を始めた涨家率 }\end{array}$} \\
\hline & 公詓事業 & それ以外 & 計 & \\
\hline $\mathrm{R}$ & $93 \%$ & $40 \%$ & $71 \%$ & 5796 \\
\hline $\mathrm{U}$ & 67 & 38 & 50 & 0 \\
\hline
\end{tabular}

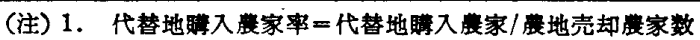

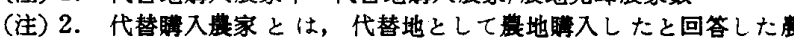

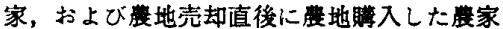

表-1 農 地 壳 却 理 由

（単位 : 回答数, 4 項目以内の選択）

\begin{tabular}{|c|c|c|c|c|c|c|c|c|c|c|c|c|c|c|}
\hline & & 公共事業 & $\begin{array}{l}\text { 相続税 } \\
\text { 支払 }\end{array}$ & 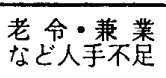 & $\begin{array}{l}\text { 隣接農地 } \\
\text { 竞 却 }\end{array}$ & $\begin{array}{l}\text { 周围の } \\
\text { 市街化 }\end{array}$ & $\begin{array}{l}\text { 園宅加ら } \\
\text { 不便 }\end{array}$ & 生産性 & $\begin{array}{ll}\text { 臨 時 } \\
\text { 費 }\end{array}$ & $\begin{array}{l}\text { 曹朋自 } \\
\text { 営資金 }\end{array}$ & 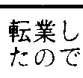 & $\begin{array}{l}\text { いい買い } \\
\text { 值かく }\end{array}$ & その他 & $\begin{array}{l}\text { 壳 却 } \\
\text { 都家数 }\end{array}$ \\
\hline \multirow{2}{*}{ 森河内 } & $R$ & 14 & 3 & 2 & 2 & 4 & 4 & 9 & 7 & 2 & 0 & 1 & 1 & $24 \bar{F}^{-}$ \\
\hline & $\mathrm{U}$ & 6 & 1 & 7 & 1 & 8 & 0 & 5 & 3 & 4 & 3 & 1 & 1 & 14 戸 \\
\hline \multirow{2}{*}{ 小曾根 } & $R$ & 12 & 5 & 0 & 3 & 3 & 2 & 0 & 0 & 2 & 0 & 1 & 0 & 14 戸 \\
\hline & $\mathrm{U}$ & 33 & 9 & 6 & 12 & 6 & 1 & 3 & 17 & 5 & 0 & 5 & 1 & 4 户 \\
\hline
\end{tabular}

表一2 㹃地売却金使途

（単位 : 回答数， 3 項目以内の選択）

\begin{tabular}{|c|c|c|c|c|c|c|c|c|c|c|c|c|}
\hline & & $\begin{array}{l}\text { 代替曹地 } \\
\text { の購入 }\end{array}$ & 山林の購入 & 農業投資 & $\begin{array}{l}\text { 䡠用自営 } \\
\text { 鉒 }\end{array}$ & 臨時出費 & 侏・眝食 & $\begin{array}{l}\text { 税金支扎い } \\
\text { 借金返済 }\end{array}$ & 生活資金 & 転業資金 & その他 & 売却農家数 \\
\hline \multirow{2}{*}{ 森 河 内 } & $\mathrm{R}$ & 13 & 2 & 1 & 9 & 9 & 2 & 6 & 4 & 1 & 0 & 24 \\
\hline & $\mathrm{U}$ & 7 & 0 & 0 & 5 & 6 & 1 & 3 & 1 & 3 & 0 & 14 戸 \\
\hline \multirow{2}{*}{ 小曾根 } & $\mathrm{R}$ & 9 & 1 & 3 & 2 & 5 & 1 & 5 & 0 & 1 & 0 & 14 戸 \\
\hline & $\mathrm{U}$ & 12 & 1 & 7 & 12 & 24 & 2 & 12 & 10 & 1 & 1 & 41 戸 \\
\hline
\end{tabular}

* 大阪大学 助手 (昭和 52 年 6 月 17 日本稿受理 - 討論期限昭和 53 年 12 月末日) 
わけであり代替地買する農家は少ない。代替地買する場 合も投機的色彩が濃い。この場合臨時的出費を賄った残 余金は農業所得の不足を補いまた生活の安定・向上を艮 る為の転用自営資金にまわされていく。

他方脱農型の場合, 公共事業関連の強制的 - 外的農地 売却は比較的少なく, 内的理由で低生産性のまた生産条 件の悪化した農地を売却していく。代替地を購入した農 家は $50 \%$ と低く, 壳却金法転業資金, 転用自営資金, 自 宅新築費等に使用されていく。また農地購入に向から場 合でも，購入目的は農業サイドのものではなく投機的色 彩の濃いものであり, 農地売却を機に一層農業離れの度 を強めている。脱農型の場合, 公共事業関連の強制的農 地買收による農業所得低下を補う為に転用自営に向かう というケースは皆無であり, 公共事業が脱農型農家の都 市化・市街化対応に与えた影響は小さいと考えられる。

(2) 転用自営 (表- $5,6,7$ 参照)

転用自営は農業継続型，脱農型を問わず，殆んどの農 家が行っている。しかし前者の場合, 昭和 40 年以降に 転用自営を始めた農家が過半数を占め, 公共事業を契機 とするケースが多いと考えられる。転用自営理由も定期 的収入, 農業継続上の補助手段等農業継続する為上考え ている層が多く, 前述した様に公共事業への農業サイド からの対応がみられる。転用自営資金の調達に際して も，土地売却農家率が脱農型よりも低く，農業経営基盤 を維持しょうとする傾向がうかがえる。なお転用自営の 場合, 自家所有地内という制限は㚣るが，どの農地を転 用するかは自由で，市街化によって生産条件が悪化し た，しかし都市的利用条件としてはより有利になった農 地を転用する事になるわけであり農業生産に対する影響 は小さい。

脱農型農家の場合, 昭和 30 年以前に全農家が転用自 営を経験しており, 近年さらに経営桩大を図った農家が 多い。転用自営理由も定期的収入 ${ }^{1)}$ ，土地売却金の有効 利用等が多く，転用自営資金む農地売却依存が大で農業

表-5 転用自営開始時期（森河内）

\begin{tabular}{|c|c|c|c|c|c|c|c|}
\hline & & 饿 泣方 & $\begin{array}{l}20 \\
\sim 29\end{array}$ & $\begin{array}{l}\theta_{i Y} 30 \\
\sim 34\end{array}$ & $\begin{array}{l}35 \\
\sim 39\end{array}$ & $\begin{array}{l}\text { 昭 } 40 \\
\sim\end{array} 44$ & $\begin{array}{ll}\text { 昭 } 45 \\
\text { 以 }\end{array}$ \\
\hline \multirow{2}{*}{ R } & 䔬繁・アパート & $1 \vec{p}$ & $0 \hat{~}$ & $0 \mathrm{Fi}$ & $8 \bar{\varphi}$ & $3 \vec{F}$ & $4 \hat{j}$ \\
\hline & 代工堎 - 代合体等 & 0 & 0 & 0 & 1 & 2 & 8 \\
\hline \multirow{2}{*}{$\mathrm{U}$} & 帒家・アパート & 5 & 0 & 0 & 10 & 3 & 2 \\
\hline & 貸工場 - 貸思体等 & 0 & 0 & 0 & 0 & 0 & 4 \\
\hline
\end{tabular}

継続型とは対照的なパターンを示しており，転用自営に より農業離れは一層その度を增しているといえよう。

2.2 現時点での農地売却意向と農業経営上の問題点

(1) 農地売却意向（表一 8,9 参照）

過去に打ける農地売却, 転用自営の結果, 農家の生活 は安定・向上し, 自宅も新築し, 相続税の支払をも済ま せ，当面必要な出費は貯蓄から賄いうる範囲で農地売却 を必要とする程の多額出費はなく，農業継続型農家，脱 農型農家とも現時点では農地売却意向のない農家が大部 分である。しかし両者の農地に対する見方には大きな隔 たりがある。即ち農業継続型の場合，農業継続する為あ るいは家の財産だから売却しないとする層が多く，農地 を生産手段2)，ないしは家産とみなしているのに対し， 脱農型の場合，必要ないから売却しないとする農家が多

表一7 転用自営資金の調達法 (単位 : 回答数, 2 項目以内の選択)

\begin{tabular}{|c|c|c|c|c|c|c|c|c|}
\hline & & $\begin{array}{l}\text { 今の } \\
\text { ま眝 } \\
\text { で蕃 }\end{array}$ & $\begin{array}{l}\text { 以地 } \\
\text { 前壳 } \\
\text { )却 } \\
\text { 土金 }\end{array}$ & $\begin{array}{l}\text { 䡆時売 } \\
\text { 法 } \\
\text { 息農 } \\
\text { 地 }\end{array}$ & $\begin{array}{l}\text { 農行借 } \\
\text { 㙝汃入 } \\
\text { - 号金 } \\
\text { 銀0) }\end{array}$ & $\begin{array}{l}\text { 親人借 } \\
\text { 墄兮 } \\
\text { •ら金 } \\
\text { 知の }\end{array}$ & $\begin{array}{l}\text { そ } \\
\infty \\
\text { 他 }\end{array}$ & $\begin{array}{l}\text { 慗量 } \\
\text { 首数 } \\
\text { 棠 }\end{array}$ \\
\hline \multirow{2}{*}{$\begin{array}{l}\text { 㷊 } \\
\text { 菏 } \\
\text { 内 }\end{array}$} & $R$ & 6 & 7 & 8 & 11 & 1 & 5 & 25 戸 \\
\hline & $\mathrm{U}$ & 1 & 8 & 7 & 7 & 0 & 0 & 14 戸 \\
\hline \multirow{2}{*}{$\begin{array}{l}\text { 小 } \\
\text { 盖 } \\
\text { 根 }\end{array}$} & $\mathrm{R}$ & 6 & 5 & 4 & 4 & 0 & 1 & 14 户 \\
\hline & $\mathrm{U}$ & 8 & 19 & 6 & 9 & 2 & 0 & $36 户$ \\
\hline \multicolumn{9}{|c|}{ 表一8 } \\
\hline & & $\begin{array}{l}\text { 家かな } \\
\text { 心らい } \\
\text { 財季 } \\
\text { 珄放 } \\
\text { ださ }\end{array}$ & 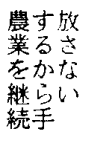 & $\begin{array}{l}\text { 売な放 } \\
\text { る心 } \\
\text { 必心な } \\
\text { 要らい } \\
\text { 加手 }\end{array}$ & $\begin{array}{l}\text { 䍡てて } \\
\text { 段はす } \\
\text { に手よ } \\
\text { よ放い } \\
\text { っし }\end{array}$ & $\begin{array}{l}\text { 農てて } \\
\text { 地はむ } \\
\text { に手よ } \\
\text { よ放い } \\
\text { つし }\end{array}$ & $\begin{array}{l}\text { そらか } \\
\text { のなら } \\
\text { 時いな } \\
\text { によい } \\
\text { なわ }\end{array}$ & 計 \\
\hline \multirow{2}{*}{ 森 } & $\mathrm{R}$ & 8戸 & 14 户 & 4 戸 & $1 戸$ & 0 戸 & 0 戸 & 27 戸 \\
\hline & $\mathrm{U}$ & 3 & 2 & 7 & 1 & 1 & 0 & $14 \vec{F}$ \\
\hline \multirow{2}{*}{$\begin{array}{l}\text { 小 } \\
\text { 曾 } \\
\text { 根 }\end{array}$} & $\mathrm{R}$ & 4 & 3 & 6 & 1 & 0 & 0 & تر \\
\hline & $\mathrm{U}$ & 12 & 7 & 12 & 11 & 1 & 1 & 44 户 \\
\hline
\end{tabular}

表一9 臨時的多額出費の調達法（森河内）

(単位回答数, 2 項目以内の選択)

\begin{tabular}{|c|c|c|c|c|c|}
\hline & $\begin{array}{l}\text { 令までの } \\
\text { 矿紊 }\end{array}$ & 葳地売却 & $\begin{array}{l}\text { 祭劦・銀行 } \\
\text { からの借入金 }\end{array}$ & $\begin{array}{l}\text { 親域等加号 } \\
\text { 借入金 }\end{array}$ & その他 \\
\hline $\mathrm{R}$ & 8 & 16 & 11 & 3 & 1 \\
\hline $\mathrm{U}$ & 9 & 8 & 5 & 0 & 0 \\
\hline
\end{tabular}

$\mathrm{R}$ 型農家の資金調達形態

\begin{tabular}{|c|c|}
\hline 農地売却䍩独型 & 6 戸 \\
\hline 農地売却+従前賍蓄型 & 3 户 \\
\hline 農地売却＋借入金型 & 7 户 \\
\hline 梴前眝蓄十借入金型 & 2 戸 \\
\hline 偕入金単独型 & 4 \\
\hline 促前貼蓄学独型 & 3 户 \\
\hline そU他 & 2 קز \\
\hline
\end{tabular}

（単位 : 回答数，3 項目以内の選択）

\begin{tabular}{|c|c|c|c|c|c|c|c|c|c|c|c|c|}
\hline & & 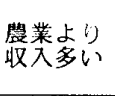 & $\begin{array}{l}\text { 定期的 } \\
\text { 貿金收入 }\end{array}$ & $\begin{array}{l}\text { 土地売却金 } \\
\text { の有効利 }\end{array}$ & $\begin{array}{l}\text { 脤棠継䊦O) } \\
\text { 補助手段 }\end{array}$ & $\begin{array}{l}\text { 老後の生 } \\
\text { 话安定的 } \\
\text { 生活保障 }\end{array}$ & 人非术足 & $\begin{array}{l}\text { 輀業して } \\
\text { 自業を } \\
\text { 始台 める }\end{array}$ & $\begin{array}{l}\text { その地を } \\
\text { 自分の元 } \\
\text { に残したい }\end{array}$ & $\begin{array}{l}\text { 㫦辺の } \\
\text { 行街化 }\end{array}$ & $\begin{array}{l}\text { 生産性の } \\
\text { 低地 }\end{array}$ & ¿0他 \\
\hline \multirow{2}{*}{ 箖 河内 } & $\mathrm{R}$ & 7 & 10 & 2 & 8 & 7 & 4 & 0 & 3 & 8 & 1 & 0 \\
\hline & $\mathrm{U}$ & 5 & 10 & 5 & 0 & 5 & 5 & 2 & 2 & 7 & 2 & 0 \\
\hline \multirow{2}{*}{ 小畺根 } & $\mathrm{R}$ & 3 & 11 & 6 & 3 & 2 & 0 & $0^{\circ}$ & 2 & 6 & 1 & 0 \\
\hline & $\mathrm{U}$ & 5 & 19 & 9 & 8 & 10 & 10 & 2 & 5 & 18 & 2 & 2 \\
\hline
\end{tabular}




\begin{tabular}{|c|c|c|c|c|c|c|c|c|c|c|c|c|}
\hline & $\begin{array}{l}\text { 農業用水の } \\
\text { 染足 }\end{array}$ & 声境漹 & 暈照・通風 & $\begin{array}{l}\text { ゴミ投乗 } \\
\text { イタスス }\end{array}$ & 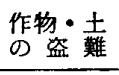 & $\begin{array}{l}\text { 周辺加ら } \\
\text { の苦 情 }\end{array}$ & $\begin{array}{l}\text { 後継者 } \\
\text { 加心ない }\end{array}$ & 人手不足 & $\begin{array}{l}\text { 経営規模 } \\
\text { 加 }\end{array}$ & 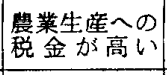 & $\begin{array}{l}\text { 農地保有への } \\
\text { 镜金加い } \\
\end{array}$ & その他 \\
\hline$R$ & 10 & 1 & 16 & 9 & 2 & 0 & 8 & 1 & 6 & 8 & 12 & 4 \\
\hline $\mathrm{U}$ & 8 & 0 & 5 & 4 & 0 & 2 & 5 & 1 & 5 & 2 & 5 & 0 \\
\hline
\end{tabular}

い。この場合農地は必要に応じて売却される事を意味し ており，脱農型の場合農地を商品視する傾向がうかがえ る。しかし農業継続型の場合でも相続税の支払い等, 多 額の出費が必要な場合は農地売却への依存が強く, 農地 を商品視しているふしもみられる。しかしその場合で も，農地売却のみに依存するのは 6 戸のみで，借入金 (7 戸)， 従前の貯蓄（3戸）といった他の資金調達法 を併用し農地売却を極力減らそうとする傾向がうかがえ るわけで，この場合農地は手放す事むある。即ち資産的 に考えられているといってよい。他方脱農型の場合, 残 存する農地も少なく, 農地売却金, 転用自営収入等によ る貯蓄も大である事から相続税も貯蓄の範围内か，一部 借入金に依れば賄いうるわけであり，農地売却への依存 度は比較的低い。

(2) 農業経営上の問題点 (表一 10,11 参照)

農業を営む上での問題点としては日照, 通風, 農業用 水, ゴミ投棄, イタズラ等の周辺市街化による農業生産 への悪影響, 後継者不足さらには農地保有に対する高額 な税金等が指摘されている。農業継続型と脱農型とを比 較すると，前者で税金問題がより強く問題視されている のがうかがえる。この事は地価上界に対する態度にも現 われており，農業継続型は税金が高くなる事から地価上 年に否定的な態度を示す層が $78 \%$ と多く，何とも思わ ないとする層は $11 \%$ にすぎない。

\section{表一11 地価上昇の影響}

\begin{tabular}{|c|c|c|c|c|c|c|c|}
\hline & 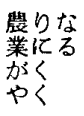 & 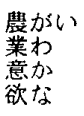 & $\begin{array}{l}\text { 税霄る } \\
\text { 金く不 } \\
\text { がな安 }\end{array}$ & 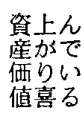 & $\begin{array}{l}\text { 何わ } \\
\text { 之な } \\
\text { 屯心 } \\
\text { 思 }\end{array}$ & $\begin{array}{l}\text { そ } \\
\text { の } \\
\text { 他 }\end{array}$ \\
\hline \multirow{2}{*}{ 柯 } & $R$ & 3戸 & 0戸 & 21 戸 & 0 戸 & 3 戸 & 0 戸 \\
\hline & U & 1 & 2 & 8 & 0 & 2 & 0 \\
\hline \multirow{2}{*}{ 冀 } & $R$ & 2 & 2 & 8 & 0 & 1 & 0 \\
\hline & $\mathrm{U}$ & 6 & 3 & 25 & 1 & 4 & 2 \\
\hline
\end{tabular}

（注）自作地のない農家の回答は除外した。

他方脱農型も地価上昇に対しては否定的な層が多いが あまり切実さはみられない。しかし農地を耕作対象ある いは家産と考えている層はすべて，税金が高くなる事か ら地価上昇を否定的にとらえている。即ち過去の大幅な 地価上昇の結果として，資産価値が大幅に増大した現時 点にお污る地価上昇とは，脱農型においてさえ当面の資 産価值の上昇よりもむしろ，中長期的な相続税額の累進 的増大として意識される事となるのである。

2.3 今後の農業経営形態・農地処分形態

(1) 農業継続意向, 農業経営形態（表一12, 13, 14 参
表-12 宅地並課税への対応

\begin{tabular}{|c|c|c|c|c|c|c|c|c|}
\hline & & $\begin{array}{l}\text { 税え農 } \\
\text { 金る業 } \\
\text { をの継 } \\
\text { 払で続 }\end{array}$ & $\begin{array}{l}\text { 税え農 } \\
\text { 金る業 } \\
\text { をよ拡 } \\
\text { 払う大 }\end{array}$ & 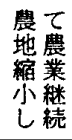 & $\begin{array}{l}\text { 農や } \\
\text { 業め } \\
\text { をる }\end{array}$ & 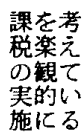 & $\begin{array}{l}\text { 何えか } \\
\text { となら } \\
\text { あいな } \\
\text { いわい }\end{array}$ & $\begin{array}{l}₹ \\
\omega\end{array}$ \\
\hline \multirow{2}{*}{$\begin{array}{l}\text { 森 } \\
\text { 河 } \\
\text { 内 }\end{array}$} & $R$ & 4 户 & 0 戸 & 1 戸 & 1 声 & $4 \vec{F}$ & 15 戸 & $1 \bar{F}$ \\
\hline & $\mathrm{U}$ & 1 & 0 & 0 & 2 & 6 & 4 & 0 \\
\hline \multirow{2}{*}{$\begin{array}{c}\text { 小 } \\
\text { 曾 } \\
\text { 根 }\end{array}$} & $\mathrm{R}$ & 4 & 0 & 2 & 1 & 6 & 1 & 0 \\
\hline & $\mathrm{U}$ & 6 & 0 & 3 & 6 & 9 & 15 & 2 \\
\hline
\end{tabular}

表一13 農業 存絖形態

\begin{tabular}{|c|c|c|c|c|c|c|c|c|c|}
\hline & & $\begin{array}{l}\text { や上来 } \\
\text { 号性 } \\
\text { 方将 } \\
\text { 亿将る }\end{array}$ & $\begin{array}{l}\text { 䋩加 } \\
\text { 精 } \\
\text { 持杯 }\end{array}$ & $\begin{array}{l}\text { 家て } \\
\text { 業続 } \\
\text { 新 } \\
\text { しる }\end{array}$ & $\begin{array}{l}\text { 息用物 } \\
\text { 老 } \\
\text { 消農作 } \\
\text { 買作る }\end{array}$ & 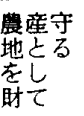 & 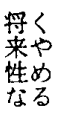 & $\begin{array}{l}\text { 考な } \\
\text { えい } \\
⿱ 亠 䒑 \\
\vdots\end{array}$ & $\begin{array}{l}z \\
0 \\
\text { 他 }\end{array}$ \\
\hline \multirow{2}{*}{$\begin{array}{l}\text { 森 } \\
\text { 漓 } \\
\text { 内 }\end{array}$} & $\mathrm{R}$ & 6 户 & 13 户 & - & 1戸 & $4 \vec{F}$ & $2 戸$ & $1 \bar{F}$ & 0 戸 \\
\hline & $U$ & 3 & 3 & - & 2 & 4 & 1 & 1 & 0 \\
\hline \multirow{2}{*}{ 小 } & $R$ & 1 & - & $4 \bar{戸}$ & 4 & 5 & 0 & 0 & 0 \\
\hline & $U$ & 2 & - & 5 & 18 & 15 & 2 & 2 & 0 \\
\hline
\end{tabular}

表一14 農業経営形態

\begin{tabular}{|c|c|c|c|c|c|c|c|c|c|}
\hline & $\begin{array}{l}\text { 農 } \\
\text { 業 } \\
\text { 業 }\end{array}$ & $\begin{array}{l}\text { 畑用徉 } \\
\text { 作自 } \\
\text { 主営 } \\
\text { 業 }\end{array}$ & 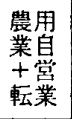 & 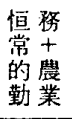 & 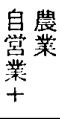 & $\begin{array}{l}\text { 曹め } \\
\text { 業る } \\
\text { は } \\
\text { や }\end{array}$ & $\begin{array}{l}わ い \\
\text { か } \\
5 \\
\$ \\
\$\end{array}$ & $\begin{array}{l}z \\
の \\
\text { 他 }\end{array}$ \\
\hline \multirow{2}{*}{ 森 } & $\mathrm{R}$ & 5 戸 & 14 户 & $-^{*}$ & 0 戸 & 1 戸 & 0 戸 & 4 戸 & $3 \mp$ \\
\hline & U & 0 & 4 & - & 0 & 4 & 2 & 4 & 0 \\
\hline \multirow{2}{*}{ 少 } & $R$ & 0 & - & 14 戸 & 0 & 0 & 0 & 0 & 0 \\
\hline & $U$ & 0 & - & 10 & 11 & 5 & 8 & 8 & 2 \\
\hline
\end{tabular}

照)

前項で述べた様に各農家とも農業経営を維持していく 上での多大な問題をかかえている。今後そういった問題 が一層梁刻化する事はあっても，解消されるとは考えら れず今後の農業継続の困難さがうかがえる。特に税金の 高額さが強く意識されている農業継続型の場合, 宅地並 課税の与える影響は大きく，宅地並課税が実施された場 合，それいの対応はわからない。何ともいえないとする 層が過半数を占め, 対応しうるとする層は $16 \%$ にすぎ ない。

他方脱農型の場合, 所得の大部分を農外所得に依存し ており,また農地面積も少ない事から，宅地並課税の影 響も小さく，楽観的に考えている首が多い。

以上の様に 農業継続型により 厳しい状況が考えられ る。そういった状況を農家はいかにしてうけとり，いか に行動しようとしているのか, 農業継続型の場合, 将来 の農業存続形態は，現状維持が精一杯であるとする消極 
的層が最む多く，これに農業縮小，廃業，財産として農 地維持等のより消極的・悲観的層を加えると $77 \%$ にも 達し，将来性ありとする層は残り $23 \%$ にすぎない。後 者の場合回答者が高年令層が多く，実質的な家計維持主 体ではないケースが多く，やや傍観者的な意見と考えら れるわけであり ${ }^{3)}$ ，農業継続型全体としていえば，より 厳しく状況をうけとめているといえよう。それを反映さ せ行動対応としての農業経営形態も畑作収入主・転用自 営収入を従とする現状維持型が過半数を占め, 農業のみ で生計を維持するというのは $19 \%$ にすぎず, 状況への 行動対応も非常に現実的であるといえよう。

他方脱農型の場合, 将来の農業依存度の一層の低下を 反映してか, 楽観的傍観者的・にとらえており，農業へ の関心は薄い。

(2) 農地処分形態 (表-15 参照)

前項で農業存続形態, 経営形態を検討した。次にさら に将来的に老令化等によって人手不足が生じた場合の農 地処分形態について検討する。

\section{表一15 農地処分形態}

(単位 : 回答数 ${ }^{* 2}$ )

\begin{tabular}{|c|c|c|c|c|c|c|c|c|c|}
\hline & & $\begin{array}{l}\text { 売 } \\
\text { 却 }\end{array}$ & $\begin{array}{l}\text { 転用 } \\
\text { 息地 } \\
\text { 㗬 }\end{array}$ & $\begin{array}{l}\text { 小し } \\
\text { 作て } \\
\text { 地貸 } \\
\text { 亡す }\end{array}$ & $\begin{array}{l}\text { 請に } \\
\text { 負出 } \\
\text { 耕す } \\
\text { 作 }\end{array}$ & $\begin{array}{l}\text { 休して } \\
\text { 耕てお } \\
\text { 地放く } \\
\text { とっ }\end{array}$ & $\begin{array}{l}\text { 貸農て } \\
\text { 震地残 } \\
\text { 園亡す } \\
\text { 等し }\end{array}$ & $\begin{array}{l}\text { 休日 ・㷌宅 } \\
\text { 後に農業し } \\
\text { てでも農地 } \\
\text { として残す }\end{array}$ & $\begin{array}{l}z \\
0 \\
\text { 他 }\end{array}$ \\
\hline \multirow{2}{*}{$\begin{array}{l}\text { 森 } \\
\text { 河 } \\
\text { 内 }\end{array}$} & $\mathrm{R}$ & 4 & 14 & 0 & 1 & 1 & 9 & 6 & 2 \\
\hline & $\mathrm{U}$ & 2 & 7 & 1 & 0 & 3 & 3 & 2 & 0 \\
\hline \multirow{2}{*}{$\begin{array}{l}\text { 小 } \\
\text { 糞 } \\
\text { 根 }\end{array}$} & $\mathrm{R}$ & 0 & 8 & 0 & 2 & 0 & - $^{* 1}$ & - & 3 \\
\hline & $\mathrm{U}$ & 4 & 22 & 0 & 4 & 1 & - & - & 6 \\
\hline
\end{tabular}

農業継続型, 脱農型とも貸家・貸工場等の転用自営用 地, あるいは貸農園, 休日農業用地, 休耕地として, 即 ち自家所有地として農地を残す事を考えており，売却を 考えている農家は非常に少ない。

その場合, 農地保全の立場からは農家がどういった農 地を農用地としてあるいは転用自営用地として利用しよ うとしているかが重要な点となってくる。

従って次に, 土地利用形態別に, 即ち農用地, 転用自 営用地さらには財産的用地として利用・残存させる場合 農家がどういった条件を重視しょうとしているかを考察 する事とする。

2.4 利用形態別の重視条件

(1) 残存農地としての条件（表一16 参照）
農業継続型, 脱農型とも先祖代々の農地 ‘)といた家 産的条件を重視する層が多い。他には前者に農地集積, 優良農地, 自宅近く ${ }^{5}$ 等の生産条件を 重視する層が多い のに対し, 後者に転用容易, 財産価值といった条件を重 視する層が多く, 農地は将来の都市的用地とみなされて いる。

条件相互間の関連をみとる, 農業継続型の 場合 先祖 代々を重視する層は，先祖代々を単独条件とするか（5 例)，自宅近く（ 5 例）をあげ，他方生産性を重視する 層汢, 農地集積, 自宅近く（各 3 例）をあげており, 前 者における農地の家産視, 後者に打ける生産手段視之同 ビ農業継続型でありながら対照的な農地観の差がみられ る。

他方脱農型の場合, 先祖代々を重視している層は同時 に財産価值 (4 例)，転用条件（2 例）をあげており， 脱農型にとって農地とは, 生産手段ではなく, また単純 な家産でもなく財産・商品といった側面が非常に強い事 を示している。

（2）転用自営用地としての条件（表一17 参照）

農業継続型は低生産性, 遠く耕作不便等の農業生産条 件を重視する層が多く, 次で先祖代々, 自宅近く等の家 産的条件を重視する層が多い。

条件相互間の関係をみると, 低生産性を重視する層は 同時に，遠く耕作不便，先祖代々（各 4 例）をあげてお り生産条件を重視する層と, 家産条件をも重視する層と にわかれる。他方先祖代々単独 ( 5 例), 自宅近く単独 ( 3 例), 先祖代々と自宅近く（2 例）等家産的条件のみ を重視する層あるいはそれと対照的に低生産性と財産価 值・転用条件（各 2 例）をあげる層むあり合理的思考を 示す層もみられる。脱農型の場合, 先祖代々 ( 5 例), 低生産性 ( 4 例), 財産価值 ( 3 例) と転用自営用地に 対する土地観はバラバラであり, 条件相互間の関係につ

表一17転用自営用地としての条件

（単位 : 回答数， 2 項目以内の選択）

\begin{tabular}{|c|c|c|c|c|c|c|c|c|c|c|}
\hline & & $\begin{array}{l}\text { 毷い } \\
\text { 近 } \\
\text { 近 }\end{array}$ & $\begin{array}{l}\text { 先 } \\
\text { 算 } \\
\text { s }\end{array}$ & $\begin{array}{l}\text { 低 } \\
\text { 生 } \\
\text { 産 }\end{array}$ & \begin{tabular}{|l} 
地<値 \\
価財 \\
少産 \\
高価
\end{tabular} & $\begin{array}{l}\text { 息遠不 } \\
\text { 便 } \\
\text { 耕 } \\
\text { 作 }\end{array}$ & $\begin{array}{l}\text { 購 } \\
\text { 農 } \\
\text { 地 }\end{array}$ & $\begin{array}{l}\text { 小貸 } \\
\text { 作付 } \\
\text { 地地 }\end{array}$ & $\begin{array}{l}\text { 特 } \\
\text { な } \\
\text { L }\end{array}$ & $\begin{array}{l}z \\
\text { の } \\
\text { 他 }\end{array}$ \\
\hline \multirow{2}{*}{$\begin{array}{l}\text { 森 } \\
\text { 菏 }\end{array}$} & $R$ & 4 & 9 & 12 & 4 & 4 & 1 & 0 & 4 & 3 \\
\hline & $\mathrm{U}$ & 1 & 5 & 4 & 3 & 1 & 1 & 2 & 4 & 0 \\
\hline \multirow{2}{*}{$\begin{array}{l}\text { 小 } \\
\text { 糞 }\end{array}$} & $\mathbf{R}$ & 5 & 4 & 4 & 1 & 2 & 0 & 0 & 4 & 0 \\
\hline & $\mathrm{U}$ & 18 & 13 & 8 & 9 & 3 & 1 & 1 & 8 & 0 \\
\hline
\end{tabular}

表一16 残存農地としての条件

(単位: 回答数, 2 項目以内の選択)

\begin{tabular}{|c|c|c|c|c|c|c|c|c|c|c|c|}
\hline & & 自宅に近い & 先祖代々 & $\begin{array}{l}\text { 農地がま亡 } \\
\text { まっている }\end{array}$ & 俊良農地 & $\begin{array}{l}\text { 市街地に近 } \\
\text { く転用容易 }\end{array}$ & $\begin{array}{l}\text { 道路加ら唯 } \\
れ \text { 市街化さ } \\
れ に く い\end{array}$ & $\begin{array}{l}\text { 財链価值 } \\
\text { の る }\end{array}$ & $\begin{array}{l}\text { 地価上㫧の } \\
\text { 条件を它つ }\end{array}$ & 特になし & その他 \\
\hline \multirow{2}{*}{ 森 河 内 } & $\mathrm{R}$ & 8 & 10 & 8 & 3 & 2 & 1 & 0 & 1 & 3 & 3 \\
\hline & $\mathrm{U}$ & 2 & 7 & 1 & 1 & 5 & 0 & 5 & 0 & 3 & 0 \\
\hline \multirow{2}{*}{ 小曾根 } & $\mathbf{R}$ & 5 & 8 & 4 & 2 & 2 & 0 & 2 & 0 & 1 & 1 \\
\hline & $\mathrm{U}$ & 21 & 11 & 7 & 3 & 11 & 1 & 6 & 2 & 6 & 1 \\
\hline
\end{tabular}


表一18 不動産としての条件（森河内）

（単位 : 回答数，2 項目以内の選択）

\begin{tabular}{c|c|c|c|c|c}
\hline & 自宅に近い & 先祖代々 & 財産よして & 地傈早早の & その他 \\
\hline $\mathrm{R}$ & 10 & 14 & 17 & 3 & 2 \\
\hline $\mathrm{U}$ & 5 & 6 & 9 & 2 & 0 \\
\hline
\end{tabular}

いても同様で，明確な傾向は見出しがたい。また特に条 件はないとする層が目立ち，全体的に転用自営用地条件 に対する無関心さがうかがえる。

(3) 財産的用地としての条件（表一18 参照）

最低限不動産として土地を残す場合，両類型とも家産 的条件，財産的条件を重視している。

条件相互間の関保では，農業継続型の場合，財産的条 件単独であげる層は少なく（4 例)，先祖代々あるいは 自宅近く（各 5 例）といった家産的条件と同時にあげて いる。また先祖代々単独 ( 5 例), 先祖代々と自宅近く

（4 例）といった家産条件のみを重視する層も多く，全 体としては家産的条件を 重視する傾向が強いといえよ う。

他方脱農型の場合, 財産価値単独であげる層が多い （4 例), 反面家産的条件との関連あるいは家産条件単独 （各 4 例）であげる層が少なく，農業継続型と比較すれ ば財産的条件を重視する層が多いといえよう。しかし家 産条件単独型，財産的条件十家産的条件型も多く，不動 産条件としては農業継続型，脱農型の間にはあまり差が

表一19 条件相互関の関保（森河内）

\begin{tabular}{|c|c|c|c|}
\hline & 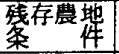 & 転用自営用地条件 & 不動産用地条件 \\
\hline \multirow{4}{*}{$\mathrm{R}$} & 先祖代々 & $\begin{array}{l}\text { 先祖代々 }(8), \text { 目宅近く(2) } \\
\text { 購入農地 (1), 低生産性 (5) } \\
\text { 遠く耕作不便 (1) }\end{array}$ & $\begin{array}{l}\text { 先祖代々(11), 自宅近く(2) } \\
\text { 斯産として価值ある(6) } \\
\text { 地価上昇の条件をむつ(2) }\end{array}$ \\
\hline & 息宅に近 & $\begin{array}{l}\text { 先祖代々 (5), 自宅近く(6) } \\
\text { 低生産性 (5) } \\
\text { 遠く耕作不便 (3) }\end{array}$ & $\begin{array}{l}\text { 先祖代々(7), 自宅近く(6) } \\
\text { 財産として価值ある(8) }\end{array}$ \\
\hline & 绶良農地 & 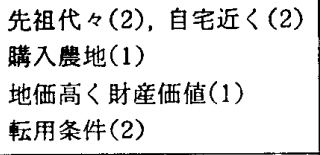 & $\begin{array}{l}\text { 先祖代々 (3)，自宅近く(6) } \\
\text { 財産として価値ある(8) } \\
\text { 地価上昇の条件 (1) } \\
\text { 転用条件 (1) }\end{array}$ \\
\hline & 農地集皘 & $\begin{array}{l}\text { 低生産性(3) } \\
\text { 遠く耕作不便 (2) } \\
\text { 転用条件 (1) }\end{array}$ & $\begin{array}{l}\text { 先祖代々 (1), 自宅近く(3) } \\
\text { 財産として価値ある(3) } \\
\text { 転用条件 (1) }\end{array}$ \\
\hline \multirow{3}{*}{$\mathrm{U}$} & 先祖代々 & $\begin{array}{l}\text { 先祖代々 }(5), \text { 購入宸地 (1) } \\
\text { 小作地 }(1) \text {, 自宅近く(1) } \\
\text { 地価高く財産価値(2) } \\
\text { 低生産性(1) } \\
\text { 遠く耕作不便 (2) }\end{array}$ & $\begin{array}{l}\text { 先祖代々(6), 自宅近く(3) } \\
\text { 盱産として価値ある(3) } \\
\text { 地価上昇の条件(1) }\end{array}$ \\
\hline & 盰产価値 & $\begin{array}{l}\text { 先祖代々 (3), 購入農地 (1) } \\
\text { 低生産性 (1) } \\
\text { 遠く耕作不便 (1) } \\
\text { 地価高く財産価値 (3) }\end{array}$ & $\begin{array}{l}\text { 先祖代々 (4)，自宅近く(1) } \\
\text { 勖産として価値ある(4) }\end{array}$ \\
\hline & 転用・売 & $\begin{array}{l}\text { 先祖代々 (1)，小作地 (2) } \\
\text { 低生座性 (1) } \\
\text { 遠く耕作不便 (1) }\end{array}$ & $\begin{array}{l}\text { 先祖代々(1), 自宅近く(1) } \\
\text { 財産として価値ある(3) } \\
\text { 地価上昇の条件(1) }\end{array}$ \\
\hline
\end{tabular}

（注） 残存農地条件のうち，3户以上の回答があった項目のみ集計。 ( )内は回答数。
ないともいえよう。

2.5 残存農地条件, 転用自営用地条件, 不動産条件 相互間の関係（表一19 参照）

(1) 農業継続型の場合

農地残存条件として先祖代々を重視する層は，転用自 営用地条件，不動産条件としても家産的条件を重視する 傾向が強く，他には転用自営用地条件として生産条件， 不動産条件として財産的条件がみられる。農地残存条件 として自宅近くを重視する層は転用自営用地条件，不動 産条件としても自宅近く，先祖代々等の家産的条件を重 視する傾向がみられる。他には先祖代々の場合と同様, 転用自営用地条件として生産条件，不動産条件として財 産的条件が重視されている。この場合農地残存条件とし ての自宅近くと, 転用自営用地条件としての自宅近くと では，土地利用上相矛盾するものであるにもかかわら す，共に重視されており，自宅近くの土地に対する農家 の強い執着心がうかがえ, 農地残存条件としての自宅近 くも，生産条件としてではなく家産的条件としてより強 くイメージされている事がわかる。即ち農地残存条件と して先祖代々，自宅近くを重視する層は，近時的な転用 自営用地条件として生産条件を考慮するが，それは当面 の生計を維持し，また家産としての農地をまむっていく 為のものであらゆる面での家産重視志向がうかがえる。 不動産条件として財産的条件を重視する層も多いが，こ の場合家産的条件と財産的条件は相矛盾するものではな く，並立的概念である。

他方農地残存条件として優良農地, 農地集積等の生産 条件を重視する層は,転用自営用地条件として生産条件, 不動産条件として財産的条件を重視する傾向が強く，比 較的合理的な思考パターンを示している。しかし不動産 条件としては家産的条件がほぼ半数を占め, 家産的色彩 の濃い事をも物語っている。

(2) 脱農型の場合

農地残存条件として家産的条件を重視する層は, 転用 自営用地条件，不動産条件に扮いても先祖代々等の家産 的条件を重視しており，農業継続型と同様の傾向がみら れる。農地残存条件として財産的条件を重視する層も， 転用自営用地条件での生産的条件重視はみられないが, 他では農業継続型と同様の傾向を示している。

他方農地残存条件として商品的条件を重視する層は, 転用自営用地条件，不動産条件としても家産的条件重視 層は少なく，土地を財産視，商品視する傾向が強い。

\section{3. 小曾根地区}

前節でやや詳細に農家意識の分析を行ったので，ここ では比較対照上有益な点を中心に報告する事とする。

3.1 過去における農家行動・行動動機

$$
\text { (表一 } 1,2,3,6,7,20 \text { 参照) }
$$

農業継続型では全農家が，脱農型もごく 1 部を除いて 
表一20 農家行動一行動開始時期 (小曾根)

\begin{tabular}{c|c|c|c|c|c|c|c|c|c}
\hline \multirow{2}{*}{} & \multicolumn{2}{|c|}{3 条売 } & \multicolumn{2}{c|}{4} & \multicolumn{2}{c|}{5} & \multicolumn{2}{c|}{ 条 } & \multicolumn{2}{c}{3 条買 } \\
\cline { 2 - 10 } & $\mathrm{R}$ & $\mathrm{U}$ & $\mathrm{R}$ & $\mathrm{U}$ & $\mathrm{R}$ & $\mathrm{U}$ & $\mathrm{R}$ & $\mathrm{U}$ \\
\hline 昭 30〜34 年 & 0 戸 & 4 戸 & 2 戸 & 2 戸 & 4 戸 & 12 戸 & 7 戸 & 9 户 \\
\hline $35 \sim 39$ & 1 & 9 & 8 & 8 & 4 & 10 & 6 & 3 \\
\hline $40 \sim 44$ & 1 & 4 & 2 & 11 & 2 & 19 & 0 & 3 \\
\hline 45 以降 & 0 & 5 & 2 & 14 & 2 & 3 & 0 & 4 \\
\hline $\begin{array}{l}\text { 行動しなかっ } \\
\text { た鹿家 }\end{array}$ & 12 & 21 & 0 & 8 & 2 & 9 & 1 & 24 \\
\hline
\end{tabular}

（注）農地転用申請から作成，公共事業は除外した。

農地売却している ${ }^{6)}$ 。売却時期は比較的早く，公共事業 が始まる昭和 46 年時点では既に, 殆んどの農家が農地 売却を経験しており，市街化による農業生産条件悪化等 の外的要因が一部考えられるとしても，主として農家側 の事情により農地売却されてきたと考えてよい。ただそ の場合, 農業継続型は必要に迫られてやむを得ず売却す るという傾向が強いのに対し, 脱農型の場合自宅の新築 等の臨時出費あるいは隣の農地の売却といった農地売却 を正当化するような売却理由が多く，やや主体的・積極 的な農地売却傾向がみられる。

以上の様に当地区の場合, 農家側からの農地売却であ り, 農業生産への影響を考慮の上農地を売却していく。 従って代替地購入等の生産維持, 建值しに向から層は比 較的少なく, 農地売却金は自宅新築費, 税金, 借金返済 転用自営資金等に向けられる事となる。また農地購入す る場合でも，地区外での購入が目立ち，生産目的ではな く投機目的で農地購入したケースが多いと考えられる。 転用自営の場合も農地売却と同様の傾向がみられ，ほぼ 全農家が転用自営を行っている。農業継続型の場合, 転 用自営面積は大きく, また転用自営開始時期も早く, 積 極的対応を示しており脱農型とは対照的である。これは 当地区の場合, 水稲単作地帯である為農業収入の増大は 期待しえず，また農外職業への転職も困難な状況下で， 家計を維持する為に転用自営せざるを得なかった事を物 語っている。他方早くから雇用労働者として析出され定 期的·安定的収入を確保している脱農層は，より一層の 生活安定・向上, 後継者流出による老後保障的意味あい 加, 兼業・老令化による人手不足む手伝って, 転用自 営に向かう事となる。

\section{2 現時点での農地売却意向 (表一8 参照)}

農地売却・転用自営の結果, 農家の生活水淮淌上し 貯蓄む大幅に增加する。また当面必要な臨時的出費もな く, 現時点では農地売却意向のない農家が多い。

しかしその理由は必要ないからとする層が多く, 他に 值段による, 農地による等の売却志向層を加えると，農 業継続型, 脱農型とも過半数が状況次第で農地売却する 意向を示しており, 農地の商品視傾向が顕著にみられ, 森河内地区と汶対象的である。

\section{3 今後の農業経営形態, 農地処分形態}

(表一13, 14, 15 参照)

以上の傾向认農業継続意向にも明膫に現われており， 積極的に農業継続するとする層はごく一部で, 他の大部 分は，家業あるいは農地を守る為とする義務的な農業継 続型か，もしくは自家消費用の米を作ればよいとする土 地持ち労働者型が多い。従って具体的な営農形態む, 農 業継続型では転用自営業十農業, 脱農型ではさらに土地 持ち労働者型, 自営業十農業型, 農業廃業型がみられ, 現状維持的ではあるが脱農業志向が明瞭にうかがえる。 農地処分形態む転用自営用地として考えている層が全体 の $60 \%$ を占め, 一応農地形態で残そうとする層は, 農 業継続型で $31 \%$ ，脱農型で $14 \%$ にすぎない。

3.4 残存農地条件, 転用自営用地条件

$$
\text { (表一 } 16,17 \text { 参照) }
$$

残存農地条件としては農業継続型, 脱農型とも自宅近 く，先祖代々といった条件を重視しており，他には農業 継続型における農地集積等の生産条件の重視, 脱農型に おける転用策件等の重視がみられる。

転用自営用地条件の場合も同様の傾向がみられる。

これを森河内地区と比較すると，当地区の場合，自宅 近くの土地を重視する傾向が強く, 特に脱農型にその傾 向がうかがわれる。この場合の自宅近くとは》，農業継 続型の場合, 森河内地区と同様, 家産的意味あいが強い が, 脱農型の場合, そういった傾向はあまりみられず, むしろ財産的, 商品的に意識されている傾向が強い。こ の事と先祖代々重視層の少ない事を勘案すると，脱農型 における家産的意識の薄弱さが明確となる。

\section{4. まとめ}

以上, 行動と対応させながら農地観・農業観を中心に 農家意識の変遷を分折してきた。要約すると, 森河内地 区の場合, 高度輪作地帯として古くから積極的な農業経 営が行なわれてきた為, 借地による経営規模桩大例にも みられるように, 農地は生産手段としてみなされてき た。その後市街化の進展にともない, 農地を商品視, さ らには財産視し脱農していく層もみられるが，他方それ を農業継続の補助手段として利用しながら積極的な農業 経営を行っている層も多い。しかし脱農層に農地を商品 視, 財産視する傾向が若干強いとはいえ, 両層とも最終 的には農地を家産十財産視しており, 農業生産と結合し て形成されてきた農民的農地観がみられる。

他方農地からの収入では生計を維持し得ず，早くから 兼業化が生じていた小兽根地区においては, 農業経験の ない層も多く，ごく一部を除いて農地は商品さらには財 産として処理され, 最終的形態においても家産視する層 は少なく, 商品視, 財産視する層が多く, 農地は農業生 産とは完全に切り離され，単なる土地にすぎなくなって いる。

しかし両地区とも，その理由こそちがえ自宅近くの農 
地・土地を重視する傾向は共通しており，そういった農 家の保有性向を充分考慮した土地利用計画，農業集落加 らの計画が必要とされよう。

具体的には, 森河内地区の場合, 農業就業者間の年令 差が大きく，彼らが農業からリタイヤーする時期は様々 である。その場合，近くリタイヤーする高年令層に貸農 園，休日農業等一匛農地形態で残そうとする傾向が強い とはいえ，相続時における農地売却あるいは老後保障の 為の転用自営は必至であり，かれらの転用自営用地条件 と残存農家の残存農地条件とが同一である以上，農業的 土地利用と都市的土地利用との競合が長期的に生じる事 となり，生産基盤条件の悪化等，残存農家への悪影響は 必至となる。

従って農地ごとの土地利用形態の変化方向, 即ち貸農 園, ホビ一用農地, 転用自営用地, 売却地等の変化方向 を把握し，土地利用間の調整を図ると同時に，借地とい った農業的土地利用の可能性の検討等も必要となろう。 小曾根地区の場合，水稲単作地帯で市街化による水利条 件の悪化は農業継続上致命的なもので，農地集積地以外 での農地残存は極めて困難な状況下にあり，農地集積地 以外では農地保全よりむむしろ，市街化の整序化を考え ざるを得ない。その場合，小作地一貸付地が市街化の正 常な方向を歪める事例が非常に多く，小作契約関係の把 握・調整が必要となる。

また農地集積地においては，労働力不足から農地かい 廃が予想されるわけであり，森河内地区と同様，農地ご との土地利用変化方向を把握・調整すると同時に, 残存 農家への農地集積，即ち借地農業の可能性の検討等が必 要となる。
本研究注大阪大学大学院生, 中塚基文氏との共同研究 の一部をまとめたものである。

注

1）脱農型の場合，農業所得は殆んどなく，また勤労所得と いってもあるかないかの農家が多い。従って脱農型にと っての転用自営からの定期的収入とは農業継続型とは異 なり，主たる収入源であり，転用自営理由として定期的 収入を重視する層が多いという事は，脱農型の農業離れ 現象の一層の進展を物語っている。

2）農民の土地観等について体系的に述べたものはないが， 安達生恒:「農政学加」, 建築雑誌 1976.7 , あるいは農 業問題研究所:「市街化前線に㧍ける農家の土地感」 1976. 3, 小林茂:「農家相続の経済学的研究」, 成文堂, 1969. 8 等で若干ふれられている。

3）今回のアンケート調查では回答者を世带主に限定した。 この場合 世帯主は農作業から引退していても, 家政から 引退していない, いわゆる「財布のおやじ培り」は済ん でいない 60 才以上層が多く, そらいった層の意見が反映 されている。

4）調查対象とした 2 地区とも，昭和 30 年以降に購入した農 地が多く，また農地改革で自作地になった農地とそうで ない農地の区別むあり，転用・売却時に「先祖代々の農 地」と「そうでない農地」との区別が生じる。

5）自宅近くといら条件は，残存農地条件としてみる場合， 生産的条件として 意識されているケースと，家産的条件 として意識されているケース，さらには双方の条件が意 識されているケースが考えられる。しかし転用自営用地 条件あるいは不動産条件として自宅近くがあげられる場 合は家産的に意識されていると考えてよい。

6）脱農型の場合，自己の所有地はもともと小規模な農家が 多く，しかもその農地も小作地・貸付地関係にあるケー スが多い。この場合農地の自由処分はできず，壳却，転 用自営したくともし得なかったのが実情であり，このた め脱農型の売却農家率, 転用自営農家率が $100 \%$ を切っ ていると考えられる。

7）森河内地区と同様，残存農地条件間，転用自営用地条件 間，さらには耐条件相互間でクロスさせ分析した。

\section{S Y N OPS I S}

U.D.C. : $711.168: 711.3$

\section{BASIC ANALYSIS ON CIRCUMSTANCES OF CULTIVATED LAND IN URBAN DISTRICT OF OSAKA PREFECTURE FOR THEIR PRESERVATION PROGRAM Part III}

by MASAKI KUSAKA, Assistant of Osaka Univ. Member of A.I.J.

This study continues the previous report part II., the following is to describe the changing process of farmers' concious mind for the urbanization. The contents of this paper are as follows;

1. On the farmers' actions and their motives for actions in the past

2. On the farmers' minds for selling cultivated lands and problems going on with farming at present

3. On the forms of having control of farming and dealing with the cultivated lands in the future

4. On the cultivated land use conditions which farmers are looking on as important for farming, selling and having

5. On the relations between their conditions 